IRA-International Journal of Management \& Social Sciences

ISSN 2455-2267; Vol.13, Issue 03 (December, 2018)

Pg. no. 84-89.

Institute of Research Advances

http://research-advances.org/index.php/RAJMSS

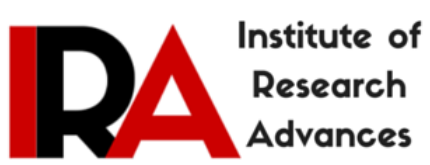

\title{
Stress and Coping: A Comparative Study between Government and Private Medical College Students in Guntur District, Andhra Pradesh
}

\author{
Masarat Jahan ${ }^{1 \#}$ and Dr. S. Anitha Devi ${ }^{2}$ \\ ${ }^{1}$ Reseach Scholar, Department of Commerce and Business Administration, Acharya Nagarjuna \\ University, Nagarjuna Nagar, Guntur, India. \\ ${ }^{2}$ Professor and Head of the Department of Management Studies, TJPS College, Guntur, India. \\ \#corresponding author. \\ Type of Review: Peer Reviewed. \\ DOl: http://dx.doi.org/10.21013/jmss.v13.n3.p2
}

\section{How to cite this paper:}

Jahan, M., Devi, S.A. (2018). Stress and Coping: A Comparative Study between Government and Private Medical College Students in Guntur District, Andhra Pradesh. IRA-International Journal of Management \& Social Sciences (ISSN 2455-2267), 13(3), 84-89. doi:http://dx.doi.org/10.21013/jmss.v13.n3.p2

\section{(C) Institute of Research Advances. \\ (cc) EY-NC}

This work is licensed under a Creative Commons Attribution-Non Commercial 4.0 International License subject to proper citation to the publication source of the work.

Disclaimer: The scholarly papers as reviewed and published by the Institute of Research Advances (IRA) are the views and opinions of their respective authors and are not the views or opinions of the IRA. The IRA disclaims of any harm or loss caused due to the published content to any party.

Institute of Research Advances is an institutional publisher member of Publishers International Linking Association Inc. (PILA-CrossRef), USA. The institute is an institutional signatory to the Budapest Open Access Initiative, Hungary advocating the open access of scientific and scholarly knowledge. The Institute is a registered content provider under Open Access Initiative Protocol for Metadata Harvesting (OAI-PMH).

The journal is indexed \& included in WorldCat Discovery Service (USA), CrossRef Metadata Search (USA), WorldCat (USA), OCLC (USA), Open J-Gate (India), EZB (Germany) Scilit (Switzerland), Airiti (China), Bielefeld Academic Search Engine (BASE) of Bielefeld University, Germany, PKP Index of Simon Fraser University, Canada. 


\begin{abstract}
Stress in medical students is a burning issue these days, prolonged stress among students is leading to different psychological disorders. The aim of the present study is to make a comparison of the stress levels experienced between a government medical college's students and private medical college's students of Guntur district, Andhra Pradesh. The total sample size of the study was 507. Findings of the study revealed that there is a significant difference between the stress experienced by government medical college students and private medical college students. Respondents were using different coping mechanisms like going to shopping/movies/watch TV/internet/listening to music to relax, keeping the sense of humor, etc., to overcome the stress. Attention should be paid to the students to address this issue.
\end{abstract}

\title{
Introduction
}

Keywords: Stress, Medical Students, Coping.

The first definition of stress was created in 1936 by Hans Selye ${ }^{[7]}$. He stated that stress is "the non-specific response of the body to any demand for change" (Institute of Stress). Selye's definition allows others to understand that stress is not merely a reaction to something bad, but merely a reaction to a change in a situation. This definition lacks an explanation of what kind of response the body has. Stress is not only a change in a body response but more specifically a "physical, mental, or emotional strain or tension" (Institute of Stress). In order for stress to form, whether it is from a good or bad situation, there must be a stressor causing tension to appear ${ }^{[11]}$.

Three ways, in which psychologists have defined stress, Psychologists have viewed the concept of "Stress" in many different ways. The first studies of stress were in early 1950, where Hans Selye (1950) defined stress as "the nonspecific response of the body to any demand." The term "Stress" had never been related to human behavior until Selye (1936) suggested using it to describe what had happened when an organism was exposed to an unpleasant stimulus. Selye (1950) was able to separate the physical effects of stress from other physical symptoms suffered by patients through his research. He observed that patients suffered physical effects not caused directly by their disease or by their medical condition.

Lazarus and Folkman ${ }^{[6,8]}$ (1984) defined stress as a pattern of negative physiological responses occurring in situations where people perceive threats to their well being which they may be unable to meet ${ }^{[5]}$.

\section{Symptoms of Stress}

Some symptoms of stress include (Institute of Stress): Reoccurring headaches, stuttering, grinding teeth, tremors/shaking, frequent sweating, insomnia, nightmares, muscle pains, depression, digestive difficulties, panic attacks, excess anxiety, decreased appetite, chest pains, reduced work efficiency, etc., ${ }^{[11]}$.

According to Folkman and Lazarus ${ }^{[6,8]}$, coping strategies can be grouped into two general types; problem-focused and emotion-focused. Problem-focused coping is aimed at problem-solving or doing something to alter the source of stress. Emotion-focused coping is aimed at reducing or managing the emotional distress that is associated with the situation. Although most stressors elicit both types of coping, problem-focused coping tends to predominate when people feel that something constructive can be done, whereas emotion-focused coping tends to predominate when people feel that the stressor is something that must be endured.

Carver $^{[3]}$ et al. and Carver have proposed 16 dimensions of coping: five dimensions assess conceptually distinct aspects of problem-focused coping (active coping, planning, suppression of competing activities, restraint coping, seeking of instrumental social support); five dimensions assess aspects of what might be viewed as emotion-focused coping (seeking of emotional social support, positive reinterpretation, acceptance, denial, turning to religion); and six dimensions assess coping responses that are less useful (focus on and venting of emotions (venting), behavioral disengagement, mental disengagement (self-distraction), humor, substance use, self-blame). These coping strategies if used effectively may buffer the unwanted impacts of the stressful situation on physical, emotional and mental wellbeing

\section{Review of Literature}

A descriptive cross-sectional survey conducted among undergraduate health professional students at Makerere

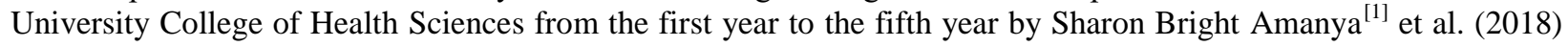


Health professional students in this study refers to students pursuing a bachelor's degree in nursing, dental surgery, and medicine and surgery. A total of 320 questionnaires were distributed to consenting students and only 258 were returned. The prevalence of stress among health professionals' students was found to be $57.4 \%$. Female students were more stressed $(60 \%)$ compared with their male counterparts. Students frequently reported academic and psychosocial stressors as most occurring.

Eliza Omar Eva ${ }^{[4]}$ et al. (2015) conducted a study on the Prevalence of stress among medical students: a comparative study between public and private medical schools in Bangladesh. A cross-sectional study was conducted among medical students of eight medical schools of Bangladesh selected purposively based on feasibility and interest of faculties in the study. The study population was 1,363 medical students from Year-III and IV. Both public and private medical schools students of Bangladesh suffered from stress. Medical students in public institution were reported to suffer more than private. Academic stress was found on the top of the list of the cause of stress.

Sohail $\mathrm{N}^{[9]}$ (2013) carried out a survey on 250 medical students studying first year, out of 250 students, 120 responded. The results also show that higher level of stress is associated with poor academic performance. Majority of the students were identified in the moderate stress category. The most important sources of stress for the students were staying in hostel, parental expectations, curriculum, tests, lack of time and facilities for entertainment. Most of the students in this study were found using combination of coping strategies. The students were found using problem solving (i.e., the use of internet chats and cell phone texting discussion with seniors) and emotion focused (walks, cooking etc.) coping strategies.

Yusoff $^{10]}$ et al. (2011), conducted a study on Prevalence of stress, stressors and coping strategies among secondary school students in Kota Bharu, Kelantan, Malaysia. A cross-sectional study was conducted on 421 students by stratified random sampling method. Prevalence of distress among female students was relatively higher compared to male students. The highest prevalence of distress was in the technical school. The academic related stressor was the major stressor in all the four types of schools. The top five most used coping strategies were religion, positive reinterpretation, use of instrumental support, active coping and planning. Distressed students tend to use negative coping strategies like denial, behavioral disengagement and self-blame rather than positive ones. Factors that contributed to distress among the students were intrapersonal and interpersonal related stressors, academic achievements, level of school and academic related stressor, attention from parent, behavioral disengagement, selfblame and planning coping strategies.

Babar T ${ }^{[2]}$. Shaikh et al. (2004), investigated on Students, Stress and Coping Strategies: A Case of Pakistani Medical School, out of 300 students 264 students filled the questionnaire. A cross sectional study was conducted on the undergraduate medical students of all five years in a medical college in Karachi find out the prevalence of stress in medical students, and to assess the different perceptions, reasons and coping methods of stress. The following are the stressors identified in the study. They are: Inability to cope, helplessness, increased psychological pressure, mental tension and too much workload. Academics and exams are the most powerful stressors. Sports, music, hanging out with friends, sleeping or going into isolation are various coping mechanisms.

\section{Objectives of the Study}

1. To make a comparative study between the stress levels experienced by private and government college students.

2. To make a comparative study between the stress levels experienced by I Year MBBS and II Year MBBS students.

3. To study the various coping strategies adopted by medical students to reduce their stress levels.

\section{Research Methodology}

The data was collected from the two medical colleges in Guntur district, one is a government medical college and the other one is a private medical college. Prior permission was obtained from Principal for the data collection. Prior to the administration of the tools, each batch was met at the lecture halls and the study was explained to them. An opportunity to ask questions were provided and clarifications were made. All students present on the scheduled date were approached to participate in the study. The study sample consisted of 507 students, 245 students from a 
Government Medical College and 262 students from the private medical college. The sampling method used for the present study was a convenience sampling method. Data collection was done by distributing a questionnaire among the respondents. Estimated time to respond to the entire questionnaire was approximately $30 \mathrm{~min}$.

\section{Data Analysis and Results:}

Table 1: Distribution of Stress experienced by Government and Private Medical College Students

\begin{tabular}{|c|c|c|c|c|c|}
\hline College & Level of Stress & Low Stress & $\begin{array}{c}\text { Moderate } \\
\text { Stress }\end{array}$ & $\begin{array}{c}\text { High } \\
\text { Stress }\end{array}$ & Total \\
\hline \multirow{2}{*}{ Government College } & No. of Respondents & 153 & 80 & 12 & 245 \\
\cline { 2 - 6 } & Percentage (\%) & 62.00 & 33.00 & 5.00 & 100 \\
\hline \multirow{2}{*}{ Private College } & No. of Respondents & 100 & 137 & 25 & 262 \\
\cline { 2 - 6 } & Percentage (\%) & 38.00 & 52.00 & 10.00 & 100 \\
\hline
\end{tabular}

From Table 1, it is observed from the private medical college $38 \%$ of the respondents experienced low stress, $52 \%$ of the sample experienced moderate stress and $10 \%$ of the sample experienced high stress, whereas, in the case of government medical college, $62 \%$ of the respondents experienced low stress, 33\% of the sample experienced moderate stress and $5 \%$ of the sample experienced high stress.

Table 2: $\mathrm{Z}$ test of Government and Private Medical College

\begin{tabular}{|c|c|c|}
\hline & $\begin{array}{c}\text { Government Medical } \\
\text { College }\end{array}$ & Private Medical College \\
\hline Mean & 1.901768707 & 2.213752024 \\
\hline Known Variance & 0.335656 & 0.3199771 \\
\hline Observations & 245 & 262 \\
\hline $\begin{array}{c}\text { Hypothesized Mean } \\
\text { Difference }\end{array}$ & 0 & \\
\hline $\mathrm{z}$ & -6.128745541 & \\
\hline $\mathrm{P}(\mathrm{Z}<=\mathrm{z})$ one-tail & $4.42873 \mathrm{E}-10$ & \\
\hline $\mathrm{z}$ Critical one-tail & 1.644853627 & \\
\hline $\mathrm{P}(\mathrm{Z}<=\mathrm{z})$ two-tail & $8.85747 \mathrm{E}-10$ & \\
\hline $\mathrm{z}$ Critical two-tail & 1.959963985 & \\
\hline
\end{tabular}

From table 2, it is observed that the test statistic $\mathrm{z}$ value is smaller than the critical value. Hence, there is a significant difference between the stress experienced by the respondents of government medical college and private medical college.

Table 3: Distribution of Stress experienced by I MBBS and II MBBS Students

\begin{tabular}{|c|c|c|c|c|c|}
\hline \multirow{2}{*}{ Year of the Study } & Level of Stress & Low Stress & Moderate Stress & $\begin{array}{c}\text { High } \\
\text { Stress }\end{array}$ & Total \\
\hline \multirow{2}{*}{ I MBBS } & $\begin{array}{c}\text { No. of } \\
\text { Respondents }\end{array}$ & 129 & 136 & 27 & 292 \\
\cline { 2 - 6 } & Percentage (\%) & 44.00 & 47.00 & 9.00 & 100 \\
\hline \multirow{2}{*}{ II MBBS } & $\begin{array}{c}\text { No. of } \\
\text { Respondents }\end{array}$ & 124 & 81 & 10 & 215 \\
\cline { 2 - 6 } & Percentage (\%) & 58.00 & 38.00 & 4.00 & 100 \\
\hline
\end{tabular}

From Table 3, it is observed that $44 \%$ of the respondents experienced low stress, $47 \%$ of the sample experienced moderate stress and $9 \%$ of the I Year MBBS students experienced high stress. In the case of II Year MBBS students, it was observed that $58 \%$ of the respondents experienced low stress, $38 \%$ of the sample experienced moderate stress and $4 \%$ of the sample experienced high stress. 
IRA-International Journal of Management E' Social Sciences

Table 4: Z test for I Year MBBS and II Year MBBS Students

\begin{tabular}{|c|c|c|}
\hline & I MBBS & II MBBS \\
\hline Mean & 2.159360731 & 1.932107118 \\
\hline Known Variance & 0.345698 & 0.330572 \\
\hline Observations & 292 & 215 \\
\hline $\begin{array}{c}\text { Hypothesized Mean } \\
\text { Difference }\end{array}$ & 0 & \\
\hline $\mathrm{z}$ & 4.356234991 & \\
\hline $\mathrm{P}(\mathrm{Z}<=\mathrm{z})$ one-tail & $6.61594 \mathrm{E}-06$ & \\
\hline $\mathrm{z}$ Critical one-tail & 1.644853627 & \\
\hline $\mathrm{P}(\mathrm{Z}<=\mathrm{z})$ two-tail & $1.32319 \mathrm{E}-05$ & \\
\hline $\mathrm{z}$ Critical two-tail & 1.959963985 & \\
\hline
\end{tabular}

From Table 4, it is observed that the calculated $\mathrm{z}$ test value is greater than $\mathrm{z}$ critical two tail value, hence, there is a significant difference between the stress experienced by I MBBS and II MBBS students.

Table 5: Distribution of Total Sample on Different Coping Strategies used

\begin{tabular}{|c|l|cc|}
\hline S.No. & \multicolumn{1}{|c|}{ Coping Strategies } & Mean & Standard Deviation \\
\hline 1 & Go to shopping/movies/watch TV/internet/listen to music to relax & 3.35 & \pm 0.80 \\
\hline 2 & Get relaxed by doing physical exercise, meditation, yoga & 2.11 & \pm 0.99 \\
\hline 3 & Slept more or less than usual & 3.01 & \pm 0.86 \\
\hline 4 & Try to keep a sense of humour & 3.12 & \pm 0.98 \\
\hline 5 & Use my past experience to try to deal with the situation & 2.91 & \pm 0.94 \\
\hline 6 & Smoke/drink Caffeinated beverages & 1.34 & \pm 0.79 \\
\hline 7 & Use alcohol to make myself feel better or think about it less & 1.13 & \pm 0.52 \\
\hline
\end{tabular}

From table 5, it is observed that:

The mean value for the statement 'Go to shopping/movies/watch TV/internet/listen to music to relax' (3.35) is high, which indicates that it is a foremost stress reliever, followed by 'Try to keep a sense of humour' (3.12), 'Slept more or less than usual' (3.01), 'Use my past experience to try deal with the situation' (2.91).

The following were the strategies which were adopted by the respondents in the least were: 'Use alcohol to make myself feel better or think about it less' (1.13), 'Smoke/drink Caffeinated beverages' (1.34), 'Get relaxed by doing physical exercise, meditation, yoga' (2.11).

\section{Limitations of the study}

The sample is geographically limited to two medical colleges of Guntur district. Other departments were not included in this study. Data collection in other districts may produce different results. Further studies should take these limitations into consideration.

\section{Conclusion}

Stress is a common problem among medical students. The level of stress varies from college to college and year of the study. Findings of the study revealed that the level of stress was low to moderate among the sample. Counseling sessions, sessions for physical activities and exercise, training on different coping strategies, managing stressors and improving peer group support will do the betterment of the condition. 


\section{References:}

[1]. Amanya SB, Nakitende J, Ngabirano TD. (2018) A cross-sectional study of stress and its sources among health professional students at Makerere University, Uganda. Nursing Open. 2018;5:70-76. https://doi.org/10.1002/nop2.113

[2]. Babar T. Shaikh, Arsalan Kahloon, Muhammad Kazmi,Hamza Khalid, Kiran Nawaz, Nadia A. Khan \&Saadiya Khan, Students, Stress and Coping Strategies: A Case of Pakistani Medical School, Education for Health, Vol. 17, No. 3, November 2004, 346 - 353.

[3]. Carver CS, Scheier MF, Weintraub, JK. Assessing coping strategies: A theoretically based approach, J Pers Soc Psychol 1989; 56: 257-283.

[4]. Eliza Omar Eva et al. (2015) a study on the Prevalence of stress among medical students: a comparative study between public and private medical schools in Bangladesh. Bio Med Central Journals, Published online 2015 Jul 30. doi: 10.1186/s13104-015-1295-5

[5]. Essays, UK. (November 2013). Three ways psychologists have defined stress. Retrieved from https://www.ukessays.com/essays/psychology/analyzing-three-ways-psychologists-have-defined-stress-psychologyessay.php?vref=1

[6]. Folkman S, Lazarus RS. An analysis of coping in a middle-aged community sample. J Health Soc Behav1980;21:21939.

[7]. Hans Selye, The Stress of Life, McGraw-Hill Book Company, New York, 1956 4-13

[8]. Lazarus RS, Folkman S. Stress, appraisal, and coping. New York: Springer; 1984;12-3.

[9]. Sohail N J Coll Physicians Surg Pak. 2013 Jan;23(1):67-71. doi: 01.2013/JCPSP.6771.

[10]. Yusoff et al. Int J Stud Res 2011;1(1):23-8

[11]. https://en.wikiversity.org/wiki/Stress_(psychological) accessed on 05-07-2018.

[12]. https://courses.lumenlearning.com/wsu-sandbox/chapter/what-is-stress/ accessed on 05-07-2018 